\title{
A European Answer to the Spanish Question: The SPD and the End of the Franco Dictatorship
}

\author{
Antonio MUÑOZ SÁNCHEZ
}

On the morning of 15 November 1975, while Francisco Franco lay dying in a Madrid hospital, the young leader of the Spanish socialists, Felipe González, appealed from the tribune of the SPD congress in Mannheim to all European democrats to contribute to the imminent resurgence of liberty in his country. $\mathrm{He}$ made this petition in a peculiar manner:

"For many years experience has demonstrated that the attitude of being willing to accept an autocratic regime in the hope of forcing its democratisation, produces the opposite effect. Today, when great expectations [for freedom in Spain] are once again being raised, we, the socialists, warn Europeans of their historical responsibility if this mistake should be repeated. All the democratic countries of Europe and the whole world have the duty to support the democratic project of the Spanish opposition". ${ }^{1}$

This quotation is specially revealing because it contradicts the prevailing explanation concerning the position of Franco's Spain in European politics, and more specifically in the process of European integration. During the last three decades scholars have broadly assumed that in spite of the growing economic interrelation with the countries north of the Pyrenees, efforts of Franco's regime to overcome its pariah status in Europe were in vain, as exemplified by the poor achievements in the EEC (Preferential Agreement of 1970). ${ }^{2}$ As the only actor able to make the Spanish society's dream of integration in the Community come true, the democratic opposition would have been, in political terms, the major beneficiary of contacts with "Europe". For Europeanism came to be identified in Spain with democracy, and turned into a powerful tool antifrancoists used in order to discredit and undermine the dictatorship, and to force it to a democratic transition after the autocrat had died. ${ }^{3}$ Following this interpretation, European socialist parties would have worked hard to set back Madrid's interest in the EEC and to support Spanish companions in their struggle for freedom. ${ }^{4}$

But a recent archive-based research questions all these assumptions and sheds light on González's words, by plainly demonstrating that the Franco regime did not

1. Quoted in Exprés Español (monthly magazine edited in Frankfurt for Spanish Gastarbeiter), n.64, p.11.

2. J.C. PEREIRA CASTAÑARES, A. MORENO JUSTE, Spain: In the centre or on the periphery of Europe?, in: A. COSTA PINTO, N. SEVERIANO TEIXEIRA (eds.), Southern Europe and the Making of the European Union, 1945-1980s, Columbia University Press, New York, 2002, pp.62-63.

3. M.E. CAVALLARO, El europeísmo y la oposición desde el franquismo hasta la Transición democrática, in: R. QUIROSA-CHEYROUZE Y MUÑOZ (coord.), Historia de la Transición en España, Biblioteca Nueva, Madrid, 2007.

4. P. ORTUÑ ANAYA, European Socialists and Spain. The Transition to Democracy, 1959-77, Palgrave, London, 2002. 
suffer any kind of pressure from the EEC to force its democratisation. ${ }^{5}$ This revelation opens a new agenda in the historiography of the Spanish-EEC relations, that has to explain accurately both the goals and means of the policies of the Six/ Nine towards the Franco regime and the influence such policies had on the process that led Spain from an autocratic to a democratic order in the 1970s. The present article wants to be a small contribution in this field. It deals with the Spanish policy of the most influential left-wing party in the EEC and argues that during the last decade of the Franco dictatorship the SPD leaders supported its participation in the process of European integration, precisely because they considered this to be the key for preparing Spain's transformation into a democracy. The first part analyses the reasons why the SPD assimilated in the mid 1960s the position of the Bonn government of seeing in the defence of Madrid's interests in the EEC the cornerstone of the West German policy toward Spain. The second part provides an overview of the implementation of this bipartisan policy during the Grand Coalition and the era Brandt. Furthermore, it points out the scarce impact the growing antifrancoism both in the German public opinion and within the party basis had on the SPD direction, unwilling to leave Spain out of the process of European détente. Finally, the third part shows how the fear that the expected selfdissolution of the regime after the death of the dictator could be disturbed by the impact of the Portuguese revolution led the government of Helmut Schmidt to introduce an element that up to then had been almost missing in the Bonn policy toward Spain: support of the democratic opposition and particularly of the party of Felipe González.

\section{West Germany on the way to a bipartisan policy towards the Spain of Franco}

The wind of détente that began to blow in German politics by mid-1963 allowed the SPD, for the first time, to look at Franco's Spain without ideologically tainted glasses. It discovered a country immersed in a frantic modernization process, with an economic policy which was exemplary for all developing countries in the world, ${ }^{6}$ and with encouraging signs of political aperturismo. ${ }^{7}$ Shortly after his election as SPD president, Willy Brandt stated to his colleagues in the executive committee that the new realities in Spain made the traditional party position aiming at isolating the Franco regime (which had inspired the rejection of Madrid's application for negociation with the EEC in February 1962) sterile, and asked for

5. F. GUIRAO, The European Community's role in promoting democracy in Franco's Spain, 1970-1975, in: J. VAN DER HARST (ed.), Beyond the Customs Union: The European Community's Quest for Deepening, Widening and Completion, 1969-1975, Nomos Verlag/Bruylant/ L.G.D.J., Baden-Baden/Brussels/Paris, 2007.

6. Thus one of the few economic experts of the SPD at that time, F. BAADE, ...denn sie sollen satt werden. Strategie des Weltkampfes gegen den Hunger, Stalling, Oldenburg, 1964.

7. Franco-Spanien gerät in Bewegung, in: SPD-Pressedienst, 04.09.1963. 
its aggiornamento. ${ }^{8}$ For the SPD leadership, strongly impregnated with modernization theories à la Rostow and perceiving European integration as instrumental to strengthening and promoting democracy on the continent, ${ }^{9}$ the search for an active policy towards Spain was not to take long. Following a new demand from Madrid to open a dialogue with the EEC, in the spring of 1964 the European experts of the party recommended that the Six should offer Spain "an economic agreement aimed at boosting the process of democratisation." 10

Following its own path, the SPD had reached similar conclusions as the Bonn government, which sought in the "Europeanization" of the Spanish economy the platform to secure West German geo-strategic interests in the Iberian Peninsula, and also a way to encourage the softening of the Franco dictatorship. ${ }^{11}$ In line with its strategy of "constructive opposition", however, the SPD tried to introduce a distinctive element into the German policy toward Spain: the promotion of democratic Europeanism within the country. To make this possible, the party decided to break the symbolic cordon sanitaire the European Left had imposed on the regime after 1945 and sent vice-president Fritz Erler to Madrid in April 1965 to lecture on the Bad Godesberg programme. During his one-day stay in Spain, Erler met with the minister José Solís, with the German ambassador Helmut Allardt, and with some members of the weak socialist opposition. He also gave a press conference where he openly stated that Spain could never join the EEC until it became a democracy. ${ }^{12}$ With federal election some months ahead, the German media unanimously applauded the shadow minister for that practical lesson in a specific Social Democratic foreign policy based on the Wandel durch Annäherung principle. ${ }^{13}$

The SPD expected that Erler's visit to Madrid would inspire other socialist parties to develop a new policy toward Spain that, starting from the pre-existing realities, would aim at strengthening civil society as the basis for the future democracy. ${ }^{14}$ But this was a futile hope. Unlike the SPD, most of the socialist parties in the EEC had not undergone a process of total desideologisation, and the

8. Archiv der sozialen Demokratie (AdsD), Bonn, SPD Parteivorstand Protokolle, session of the SPD executive committee, 11.04.1964.

9. J. BELLERS, Reformpolitik und EWG-Strategie der SPD. Die innen- und aussenpolitischen Faktoren der europapolitischen Integrationswilligkeit einer Oppositionspartei (1957-63), tuduv, München, 1979.

10. AdsD, NL Käte Strobel 66, text draft (eventually changed) of Käte Strobel, president of the socialist fraction in the European Parliament on proposals for foreign relations of the EEC, to be presented in the $6^{\text {th }}$ Congress of socialist parties of the EEC to be held in Rome in September 1964, n.d. [c. May 1964].

11. B. ASCHMANN, Treue Freunde? Westdeutschland und Spanien, 1945-1963, Franz Steiner Verlag, Stuttgart, 1999. C. SANZ DÍAZ, España y la República Federal de Alemania (1949-1966). Política, economía y emigración, entre la Guerra Fría y la distensión, Universidad Complutense, Madrid, 2006.

12. AdsD, Helmut Schmidt Archiv 5038, report of Erler to the SPD fraction on his visit to Spain, 04.05.1965.

13. Wahlfahrt zum Caudillo, in: Christ und Welt, 05.02.1965; Erlers Stippvisite, in: Die Zeit, 09.04.1965.

14. Spanien, in: Parlamentarisch-Politischer Pressedienst, 09.04.1965. 
myth of the Civil War offered a huge resistance to attitudes that could be considered by the basis or by other European companions as a concession to the regime and a betrayal to Spanish democrats. This perception was fed precisely by the Spanish member of the Socialist International (PSOE) whose leaders, living in exile since 1939, still dreamed of defeating the regime through external pressure. ${ }^{15}$ If the European democrats did not want to be involuntary collaborators of fascism, they should avoid any contact with Spain, even with Spanish socialists, for they were tolerated and even sponsored by a regime willing to convince the Six that it was undergoing a process of political liberalization. Following this reasoning, the PSOE had denounced the EEC Council's decision in June of 1964 to start a dialogue with Madrid as a "vexatious act for the dignity of the Spanish people"16 and criticized Erler's stay in Madrid as an intolerable reward to Franco's efforts to obtain international recognition. ${ }^{17}$ Given the mixed reaction of silence and open criticism to Erler's visit among Spanish, European, and American colleagues, the SPD took note that it was alone in defending a pragmatic policy towards Spain, and that further public displays should be avoided so as not to smash more porcelain in the holy temple of anti-francoism. ${ }^{18}$

In 1966, the Spanish regime was at the peak of its aperturismo and social support. Dazzled by a fully coloristic, vibrating, and apparently content Spain, which had already become the destiny for over one million German tourists yearly, West German media portrayed Franco on the 30th anniversary of the Civil War largely as a modernizer and a paternalist dictator. ${ }^{19}$ Even intellectuals close to the SPD, such as Golo Mann, contributed to this view. Mann asserted that the Spanish regime was flowing gently toward its own end, due to the smooth push of a society that was becoming more dynamic every day. In his opinion, European political forces could contribute to secure a peaceful transition after Franco's death if they withdrew from their agenda any kind of pressure on the regime and dared to establish regular contacts with all sectors of Spanish society to promote democratic thinking. Mann was extremely critical of the idealization of the Civil War among the European Left and especially of the Spanish exiles, that were incapable of

15. F. GUIRAO, The Spanish Socialist Party, in: R.T. GRIFFITHS (ed.), Socialist Parties and the Question of Europe in the 1950's, E.J. Brill, Leiden/New York/Köln, 1993.

16. Historical Archives of the European Union, Florence, European Movement 1538, communiqué of the Spanish Federal Council of the European Movement (controlled by the PSOE), 03.06.1964. The liberal Salvador de Madariaga resigned from his post as president of this Council because he did not agree with the content of this communiqué. See L. ARRIETA ALBERDI, Estación Europa. La política europeísta del PNV en el exilio (1945-1977), Tecnos, Madrid, 2007, p.314.

17. Archivo de la Fundación Largo Caballero, Madrid, 372-1, Pascual Tomás (PSOE President) to Omer Bécu (ICFTU Secretary General), 16.04.1965.

18. AdsD, NL Fritz Erler 154, report of Hans-Eberhard Dingels (SPD International department) on the visit of Rodolfo Llopis (PSOE secretary general) to Germany, 08.09.1965.

19. R. WOHLFEIL, Der spanische Bürgerkrieg 1936-1939. Zur Deutung und Nachwirkung, in: Vierteljahreshefte für Zeitgeschichte, 2(1968), pp.101-119. 
recognizing their own blame in the collapse of the democratic Republic in the 1930 s and of working for national reconciliation. ${ }^{20}$

Those opinions had a deep and long-lasting effect on SPD leaders, and reinforced their conviction that a constructive European policy aiming at preparing Spain for democracy was incompatible with declamatory statements and a strong ethical pose. ${ }^{21}$ Taking into account the expectations of a positive evolution within the regime and the unwillingness of exiles and European socialists to create a useful and realistic fusion between antifrancoism and Europeanism, the SPD assumed in 1966 the apparently contradictory central idea of the conservative German government's position towards Spain: only by contributing to the stability of the Franco dictatorship and its EEC aspirations the country would see the rise of democracy one time in the future. ${ }^{22}$

On 23 November 1966, the European Commission submitted to the Council its final report on the exploratory talks with Madrid that had lasted two years. ${ }^{23}$ It presented three alternatives the EEC could offer Spain to regulate future relations, the most ambitious of them being association. A few days later, a Grand Coalition was formed in Bonn and the Madrid authorities had to face the uncertainty whether they could rely on the new German government to defend their interests in Brussels at that moment when Spain's future in the EEC was to be decided. No sooner had Willy Brandt taken office as Foreign Minister that he decided to assuage their doubts by sending his Secretary of State, Rolf Lahr, to Madrid to tell the Spanish government that the historical political change in Bonn was in no way to alter traditional friendly relations between both countries. As in the past, the FRG would fully support Spain's cause in the EEC. ${ }^{24}$

\section{The policy pursued by the SPD towards Spain during the Grand Coalition and the Era Brandt}

The attitude of the new German government towards Spain reflects its big expectations of an EEC enlargement, that were very soon deceived by Charles De

20. G. MANN, Auch unter Franco wächst die Freiheit, in: Die Zeit, 28.01.1966; Korrekturen am Spanien-Klischee, in: Die Zeit, 11.02.1966; Hoffnung für Spanien, in: Die Zeit, 04.03.1966.

21. As Foreign minister, Willy Brandt referred to Mann's articles to base his own opinions about Spain. Politisches Archiv des Auswärtigen Amtes (PAAA), Berlin, B1/338, Willy Brandt to Knut Nevermann (student leader at the Free University Berlin), 20.03.1967.

22. B. ASCHMANN, The Reliable Ally: Germany Supports Spain's European Integration Efforts, 1957-67, in: Journal of European Integration History, 1(2001), pp.37-51.

23. Brussels Archives Commission, 17/1969, Rapport de la Commission au Conseil au sujet des conversations exploratoires avec 1'Espagne, 23.11.1966.

24. Brandt unterstützt Spaniens EWG-Wünsche, in: Frankfurter Allgemeine Zeitung, 09.12.1966. 
Gaulle. ${ }^{25}$ Though Spain had no real chance of association because of the opposition of the Benelux countries and Italy, the German delegation in the Council defended this ideal option for Spain until Madrid decided to give it up. ${ }^{26}$ The SPD even made it public with an article by the Euro MP Hans Apel. He argued that, given the ambiguity of the Rome Treaty on requirements to associate with or to join the EEC, the Spanish request for association needed a political answer from the Six. This answer could only be a positive one, for such an agreement would increase the intensity of the relations between Spain and Europe, which were the motor of all positive economic, social, and political changes the Iberian country had gone through in recent years. Associating Spain to the EEC was therefore not to underpin the Franco regime, but "to secure today the goals of the defeated Republicans". Apel comforted those who feared that the democratic essence of the EEC would suffer from an association with a dictatorship, by stating that the expected enlargement to the North would reinforce the progressive character of the European integration process and make the "Spanish adventure" less risky. ${ }^{27}$ In a meeting of the SPD fraction, Willy Brandt made Apel's arguments his own and stated that the Council would at least agree to grant Spain a status "close to an association". ${ }^{28}$ In the end, France and Germany were not able to shift the other countries from their positions and Madrid had to content herself with negotiating an agreement on the creation of a customs union. ${ }^{29}$ Bonn considered this a really poor offer that the EEC made to Spain, but at least it was a starting point, given the fact that in order to achieve this it had been necessary to overcome "a great number of difficulties which were not only of an economic but above all of a political nature". ${ }^{30}$

Ironically, the same Zeitgeist that supported in the late 1960s normalization policies towards communist dictatorships, hindered those same policies to be applied to the Franco regime (and the Salazar regime). The student revolts, the democratic activism of the Gastarbeiter, the closer attention paid by public opinion to injustices perpetrated in those countries, and the emergence of a new and brutal right-wing regime in Greece - all these factors complicated the relations between the European democracies and the Iberian autocracies, which had almost learned to treat them as they were. ${ }^{31}$ In Spain's case, the brake on reforms and the rebirth of repression applied to trade unionists and students after 1967 were now followed

25. H. TÜRK, Die Europapolitik der Grossen Koalition, 1966-1969, Schriftenreihe der Vierteljahreshefte für Zeitgeschichte, 93, München, 2006, chapters I-II.

26. PAAA, B20/200-1262, note of the Auswärtiges Amt on the German position in the next meeting of the European Council at 8 February 1967.

27. H. APEL, Spanien und die EWG, in: Pressemitteilungen und Informationen, 16.01.1967.

28. AdsD, SPD-Bundesfraktion, 5 WP, 50, meeting of the SPD fraction, 17.01.1967.

29. B. ASCHMANN, The Reliable Ally ..., op.cit., pp.44-45.

30. PAAA, B20/200-1263, note of the Auswärtiges Amt on the German position in the next meeting of the European Council at 10-11 July 1967.

31. F. BONDY, Umgang mit Diktaturen: Griechenland, Spanien, Portugal, unknown publication, n.d. [c. April 1968], to be found in: PAAA, B1/339. 
with interest by the German media, and strongly affected the quite benevolent image of the regime.

Within the SPD, the up to then marginal voices of those who did not approve of the pragmatic line their leaders took towards Spain began also to emerge. That was especially the case with Hans Matthöfer, MP and IG Metall official, personally committed to the group of socialist Spanish Gastarbeiter. ${ }^{32}$ Annoyed by Apel's article, by the visit of SPD members of Parliament invited to Spain by the regime, by the declaration of Karl Schiller in favor of the Spanish association, and by the unusual number of Spanish ministers visiting Bonn lately, Matthöfer publicly denounced the German government's strategy to make Franco's Spain "presentable little by little in the eyes of German and European public opinion". Moreover, he claimed Bonn should not be the "spokesman" for Spain in the EEC, and that the SPD ministers should respect the resolutions of the European socialists and trade unions, and not allow any EEC-Spain agreement until Madrid had shown its willingness to respect civil rights. ${ }^{33}$

As Franco's death approached, tensions among the "families" inside the regime grew. In this fight, the aperturistas searched for support among friendly governments, and especially from France and Germany. Presenting themselves as crypto-democrats harassed by the strong reactionary forces of the establishment, ${ }^{34}$ they insisted that for them the key element for being able to control the post-Franco era was the pursuit of Spain's rapprochement to Europe. The pressure of public opinion in Europe should therefore not affect the ongoing negotiations between Spain and the EEC. If the Preferential Agreement did not meet the high expectations that had arisen in terms of economic benefits for Spain, this would automatically lead to a general discredit of Europeanism within the regime and to a strengthening of the autarchy-nationalistic sectors. They would turn their back to Brussels and impose a definitive break with the political aperturismo. These arguments were a mantra in many private conversations, such as that between Foreign minister Fernando Castiella with chancellor Kurt-Georg Kiesinger in Madrid during the only official visit by an elected European head of government to Franco's Spain. ${ }^{35}$ Ambassador Helmut Allardt and his replacement after 1968, Hermann Meyer-Lindenberg, shared this point of view and permanently advised their government that an obstacle in the European aspiration of Spain would

32. The IG Metall was specially proud of its proselytism among the Spanish Gastarbeiter. In 1965, the affiliation rate of foreign metal workers was $21 \%$, whereas among the Spaniards it reached $30 \%$ (20.284). That same year, $35 \%$ of their German colleagues were IG Metall members. See A. MUÑOZ SÁNCHEZ, Entre dos sindicalismos. La emigración española en la RFA, los sindicatos alemanes y la Unión General de Trabajadores, 1960-1964, in: Documentos de Trabajo de la Fundación $1^{\circ}$ de Mayo, Madrid, 2008.

33. H. MATTHÖFER, Seltsames Zusammenspiel zwischen Bonn und Madrid, in: Frankfurter Rundschau, 03.08.1967.

34. An extreme case was Foreign minister Gregorio López Bravo, who joked with Walter Scheel in the spring of 1970 that he might one day ask for political exile in West Germany and join the FDP. Akten zur Auswärtigen Politik der Bundesrepublik Deutschland (AAPD), 1970, doc.172.

35. AAPD, 1968, doc.355. 
heavily affect the already difficult walk the country was pursuing towards a democratic future - "two steps forward, one back". 36

Foreign minister Willy Brandt took these warnings very seriously and paid less attention to those who called on him to cool down relations with Spain. Consequently, he agreed to holding consultations with Castiella in Madrid and scheduled the visit for April 1968. Neither the Spanish socialists, nor influential sectors of the European and German Left were able to convince him to renounce to that visit. ${ }^{37}$ What his comrades could not achieve came about because of the poor relations between Brandt and Kiesinger, for the chancellor himself decided, without consulting his minister, to visit the Iberian Peninsula that same year. ${ }^{38}$ In the winter of 1969, a state of emergency of two months in Spain led to rallies in major German towns and to public criticism of Bonn's friendly position vis-à-vis the Franco regime, clumsily displayed during those weeks by conferring the FRG Great Cross of Civil Merit on minister Manuel Fraga. ${ }^{39}$ Even now, Willy Brandt remained impassive. All he agreed to do was to reduce temporarily the most visible demonstrations of harmony with Madrid (the bestowal of decorations and visits by ministers) in order to avoid being considered by the Spanish opposition and by European countries, where there was a strong anti-Franco current, like in Holland and Scandinavia, "as if we were supporting the regime unconditionally". 40 Regarding negotiations between the EEC and Spain, Bonn decided to support Madrid interests,

"in order to continue to strengthen the liberal element within Spain's present political reality. In so doing we are serving Spain's long-term interests more than by a purely negative position". ${ }^{41}$

A week after the formation of the social-liberal coalition in Bonn in October 1969, Franco put together a new cabinet dominated by those technocrats who were responsible for engineering the economic boom in the 1960s that had turned Spain into the $10^{\text {th }}$ economic world power. This government presented the improvement of Spain's relations with the EEC as one of its main goals. The Preferential Agreement to be signed shortly, although highly beneficial to Spanish interests, should only be the first step on a path that contained further ambitious objectives. Considering the insuperable political obstacles to adhesion as long as Franco was alive, Madrid would pursue an association, and in order to achieve this, it was

36. PAAA, B26/389, Allardt to Auswärtiges Amt on Spanish politics, 10.10.1967.

37. AdsD, IMB 885, Otto Brenner (IG Metall president) to Brandt, 13.03.1968; AdsD, WBA A7/4, Claus Sönksen to Karl Wienand (MP), 25.03.1968; AdsD, WBA A11.1/1, Brandt to Brenner, 19.03.1968.

38. After knowing Kiesinger's decision, Brandt cancelled his visit to Madrid. PAAA, B1/339, secretary of State Paul Frank (from Abidjan) to Auswärtiges Amt, 29.03.1968.

39. Hans Matthöfer took this issue to debate to the Bundestag. Verhandlungen des Deutschen Bundestages, fifth legislature, session of 28 February 1969, pp.11852-11854.

40. PAAA, B26/387, note of Dr. Hansen (Auswärtiges Amt) on the German reaction to the state of emergency in Spain, 26.02.1969, signed by Brandt at 01.03.1969.

41. PAAA, B20/200-1484, internal report of Auswärtiges Amt on EEC-Spain relations, 26.02.1969. 
ready to take the necessary "internal political measures, which are designed to give Spain a democratic face". ${ }^{42}$ Bonn approved this pro-European government, and decided to support the expectations it placed in the EEC, searching to offer Spain "a dynamic association, one that could be developed in the direction of a full membership, not just a static final product". 43 This was noting but a relaunch of the idea expressed by Hans Apel in 1967 by taking advantage of the - this time real enlargement towards Northern Europe in order to allow Spain to develop its relations with the EEC up to the highest possible level as long as Franco was still alive. By doing so, the aperturistas, now a majority in the government, should be able to pave the way for democracy that would arise after Franco's death, something Bonn considered achievable by developing all options of the regime's "constitution". 44

But the final years of the Franco dictatorship were to be much less quiet than anybody could have expected, also with regard to its relations with Europe, where hostility against the Mediterranean autocracies was rising. After 1970, labour conflicts and democratic activism became endemic in some industrial regions of Spain. Obsessed with public order and lacking legal instruments to channel social unrest, the regime answered with repression. This multiplied abroad the echo of the conflicts, heavily damaging the aperturista image of the government and making its desire for an association with the EEC vanish. The point of no return came in December 1970 when a military tribunal in Burgos sentenced three ETA members to death. Europe felt a first wave of protest against the Spanish regime, until Franco decided to commute the sentences to life imprisonment. These rallies throughout Europe were met in Spain with orchestrated demonstrations of public support for the Caudillo that reinforced the inmovilistas opposed to the reforms. ${ }^{45}$

Within the SPD, solidarity with the Spanish democratic movement became an inherent element in the revived leftist wing in the party, that was tolerated by its leaders at government level with growing annoyance. ${ }^{46}$ Hans Matthöfer continued to be the key figure: he believed that as the sole left-majority government in the EEC, the Brandt-Scheel coalition had an important role to play in accelerating the arrival of democracy in Spain by putting pressure on a regime already in crisis. ${ }^{47}$ In February 1970 Matthöfer gathered 159 signatures among the 237 SPD members of parliament to support a document the Spanish democrats had handed over to Franco calling for reforms. In the following months he also started some initiatives to back Spanish democrats and especially that young socialist who tried to take

42. PAAA, B20/1852, report of the German embassy on Walter Scheel's visit to Spain, 12.03.1970.

43. PAAA, B1/340, report of Auswärtiges Amt on the new Spanish government, December 1969.

44. Ibid.

45. C. MOLINERO, P. YSÀS, La anatomía del franquismo, Crítica, Barcelona, 2008, pp.141 f.

46. See the contrast in this respect to Dutch socialists, M. DRÖGEMÖLLER, Zwei Schwestern in Europa. Deutsche und niederländische Sozialdemokratie 1945-1990, Vorwärts Buch, Berlin, 2008 , chapter 4.

47. H. MATTHÖFER, Der Kampf um Demokratie in Spanien, in: SPD Pressedienst, 13.02.1970. 
control of the PSOE with the intention of transforming that club of old exiles into an active organization in Spain. ${ }^{48}$

In the face of growing antifrancoism north of the Pyrenees, the regime feared that its European journey, started with the Preferential Agreement signed in June 1970, could turn into a terrible ordeal. Considering intolerable some statements coming from the EEC Commission and Parliament following the death-penalties in December 1970, Madrid informed Bonn that it did not rule out the possibility of cancelling the Preferential Agreement if the EEC was thinking about interfering in its internal affairs in the future. ${ }^{49}$ Although the German government did not believe the Spaniards would go as far, it took the negative consequences of an increase in external pressure during the final period of Francoism very seriously. So, former expressions of a friendly approach to Spain, like official visits, decreased, so as not to disturb the SPD basis and the German public opinion, but at the same time Bonn searched to diminish the effects of the antifrancoist activism in Europe both in bilateral and in EEC-Spain relations. During the Burgos trial, the Spanish ambassador in the FGR informed his minister, with satisfaction, that the coalition parties had managed to avoid any official declaration on the issue as well as a debate in the Bundestag, "though, as [secretary-general of the SPD] Hans-Jürgen Wischnewski told me, they were under huge pressure". ${ }^{50}$ Furthermore, Bonn assured Madrid that the EEC Council would not yield to the claim of the socialist fraction of the European Parliament to impose political stipulations on Spain for the development of the Preferential Agreement, by arguing that the agreement had "purely an economic character". ${ }^{51}$ At the end, the "depoliticization" of the EECSpanish relations came to be a golden rule for the Brandt-Scheel coalition. When in February 1974 the young anarchist Salvador Puich Antich was sentenced to death, the German presidency proposed that the Council should not ask Madrid for reprieve, as it was out of its domain "to take a position on internal political events in other countries". 52

Despite the growing influence of the opposition to Franco, the SPD leaders didn't even take into remote consideration the possibility that it could in some way destabilize the dictatorship. ${ }^{53}$ The advent of democracy in Spain after the Caudillo's death, whatever sort of democracy it should be, became therefore, in their mind, only possible through a slow process of evolution totally controlled by

48. P. ORTUÑO ANAYA, European Socialists ..., op.cit., pp. $158 \mathrm{f}$.

49. PAAA, B20/1854, German ambassador to the EEC Hans-Georg Sachs to Auswärtiges Amt on his conversation with Alberto Ullastres, Spanish ambassador to the EEC, 12.02.1971.

50. Archivo del Ministerio de Asuntos Exteriores, Madrid, uncatalogued records, "Política Exterior 1970", box 6, José de Erice to López Bravo, 31.12.1970.

51. PAAA, B20/1854, Sachs to Auswärtiges Amt on the meeting of the group to discuss current issues of the EEC Council, 15.02.1971.

52. PAAA, Zwischenarchiv 105669, note of Auswärtiges Amt on Puich's coming execution, 26.02.1974.

53. Madrid: Das grosse Warten auf die Zukunft, in: Parlamentarisch-Politischer Pressedienst, 02.04.1973. 
the government. ${ }^{54}$ After 1972, at the very latest, Bonn knew that Prince Juan Carlos de Borbón (who had been nominated by Franco as his successor in 1969) intended to achieve democracy as king of Spain and was also aware that the inmovilistas within the establishment represented the main obstacle to his plans. ${ }^{55}$ Therefore, the Brandt government considered that it could best contribute to the future transition by conveying to those sectors that it was the regime itself and not the opposition who held the key for the entrance of Spain to the EEC, for it was enough that the country would follow the path initiated by the reforms announced in 1969. Walter Scheel expressed this idea publicly in Madrid in 1972:

"[We] would be satisfied if the process of harmonization of the economic and political structures which is required [for Spain] to join [the EEC] made further progress. Harmony does not mean identity". ${ }^{56}$

These thoughts reflected the marginal role the social-liberal coalition attributed to the relations with the Spanish democratic movement. When Scheel was forced to counter the bad impression that had left behind in the German public opinion the signing of a 200 million DM loan for development aid to Spain in the spring of 1970, he included as part of the agenda of his visit to Madrid a meeting with four well-known members of the "tolerated opposition". ${ }^{57}$ A similar meeting with representatives of the illegal opposition, such as the PSOE, was though unthinkable for the Bonn government, for the Spanish authorities would "see this as an intolerable interference in their internal affairs". ${ }^{58}$

The "non-ideological" policy of the Brandt-Scheel coalition toward Spain and its unconditional support of Madrid's interests in the EEC disturbed and confused many Spanish, German, and European socialists. The PSOE thanked the SPD for the support it gave to those of its members who had suffered retaliation in Spain, but at the same time lamented in silence the appeasement approach of its leader to the dictatorship. ${ }^{59}$ However, when Foreign minister Scheel met in Madrid with the leader of the tolerated "socialists" and not with the Spanish member of the Socialist International, the PSOE considered that the SPD had gone much too far in its lack of solidarity and dared, for the first time, to publicly express its opinion about Brandt's policy toward Franco's regime:

54. PAAA, Zwischenarchiv 101440, report of the FRG embassy on Spanish politics in 1973, 25.01.1974.

55. PAAA, B26/454, report on the visit of Prince Juan Carlos to Bonn, 09.10.1972.

56. PAAA, Zwischenarchiv 105669, report of Ruyter (Auswärtiges Amt) to secretary of State Hans Apel on EEC-Spain relations, 23.03.1973.

57. Archiv des Deutschen Liberalismus, Gummersbach, Bestand Bundesparteitag, A12-88, speech of Walter Scheel to the FDP congress, 26.04.1970.

58. PAAA, B26/453, Meyer-Lindenberg to Auswärtiges Amt on the next Spanish visit of Scheel, 20.01.1972.

59. Archivo de la Fundación Pablo Iglesias, Alcalá de Henares, AE-595-9, Rodolfo Llopis to Rolf Reventlow (SPD journalist, in 1937 joined the PSOE and the Spanish Republican Army), 27.03.1968. 
"[The SPD finds] that only a rapprochement between the two Germanys can lead to a liberalization of the communist dictatorship of Walter Ulbricht. [...] But that analysis when applied to Spain is false by the experience of more than 30 years of Franco's dictatorship. [...] The half-measures result in a complicity in the oppression of the Spanish people". ${ }^{60}$

With reference to socialist parties of the EEC, the SPD was convinced they were much too radical, and refused to back initiatives geared to put real pressure on Franco. ${ }^{61}$ By this attitude, the powerful SPD helped to enable Madrid to "ignore, almost with disdain, those voices which argue that the socialist parties of Europe are a barrier to Spain's bid for closer EEC ties".62 In late 1972, when the negotiations to adapt the Preferential Agreement to the enlarged EEC were settled, German trade unions and the Spanish Left demanded in vain of the SPD that political reforms should also be considered on the negotiating table in Brussels, for this was the "principal - or only - method of external pressure which could force a change in the regime's way of thinking and lead to some measure of democratic liberalization". ${ }^{63}$ On the other hand, Hans Matthöfer and other SPD members who strongly supported antifrancoists in the FRG were often upset by the fact that some colleagues in the government worried less about those comrades and more about the strain their activities put on bilateral relations, and especially about the risk involved to some German investments in Spain, such as, for example, the introduction of the PAL colour TV system. ${ }^{64}$

When the era Brandt approached its unexpected end, the social-liberal coalition drew up a positive balance of its friendly relations with Spain. Contrary to the Portuguese dictatorship, which had used economic and political links with the FRG and other European democracies only to stabilize the system and to pursue its imperial fantasy, ${ }^{65}$ Francoism seemed to be moving, slowly but surely, down a path which would lead towards its own disappearance in the course of its assimilation within Europe. Although reforms announced in 1969 had led to nothing, the question of "political development" was already omnipresent. The debate was not whether the country should turn into a democracy but how a democracia a la española could be reached. Spanish leaders were surely not democrats, but they

60. Adelante con los faroles, in: Le Socialiste (PSOE official weekly newsletter), 14.05.1970.

61. On occasion of the Burgos trial, the SPD imposed to the annoyed comrades a resolution that did not condemn explicitly the Franco regime. AdsD, SPD Parteivorstand 2811, Veronika Isenberg (SPD International department) to Dingels on the session of the Bureau of Socialists parties of the EEC, 21.12.1970.

62. Thus a socialist Spanish group. AdsD, SPD Parteivorstand 11423, report of the Partido Socialista del Interior on Spain-EEC relations, 29.09.1972.

63. Idem. AdsD, WBA A11.2/15, Ludwig Rosenberg (DGB President) to Willy Brandt, 28.09.1972; and Brandt's answer, 09.11.1972.

64. See for instance the critics of Matthöfer to the reaction of the chancellery to the detention and prosecution in Spain of Carlos Pardo, responsible in Frankfurt of the IG Metall office for Spanish members and editor of Exprés Español, who was accused of offences to Franco in this magazine. AdsD, SPD-Bundesfraktion VI. WP, 211, Hans Matthöfer to Egon Bahr, 07.06.1971.

65. A. MUÑOZ SÁNCHEZ, La socialdemocracia alemana y el Estado Novo (1961-1974), in: Portuguese Studies Review, 13.1-2(2005), pp.477-503. 
were very well aware that after Franco the legitimacy of the regime and the monarchy would rapidly vanish if they were not able to fulfil the "manifest destiny" of the nation: integration in the EEC. To bring about democracy without breaking the regime was exactly the goal of the new government of PM Carlos Arias Navarro, constituted in January of 1974. Although he was a strict Francoist with a sinister past, Arias presented himself as a liberal man with a surprising reform program that should permit the country to count with "political associations" as ersatz for political parties. Considering the massive depoliticisation among Spaniards, the disorganization of the inmovilistas after the recent killing by the ETA of their natural leader, PM Luis Carrero Blanco, and the fact that the Spanish army seemed to support reforms, the SPD considered by March 1974 "the chances for a genuine liberalization, which, of course, can only be effective over the long term" quite high. ${ }^{66}$

\section{Afraid of a Portuguese infection: Helmut Schmidt and the agony of the Franco regime}

The hope placed by the SPD and very especially by Willy Brandt in a European Peace Order where all dictatorships would gently evolve, without external pressure, towards some kind of liberal-democratic order just magnetically drawn to the EEC, ${ }^{67}$ was disturbed by the deep instability that suddenly seized the continent, and especially its southern flank, after $1974 .{ }^{68}$ How the FRG, as the western country less affected by economic depression and most interested in maintaining détente and the status quo responded to this Mediterranean crisis is a question of great interest historians have not answered yet. ${ }^{69}$ In Spain's case, there is no doubt that the German position was influenced by the fear the transition towards the postFranco era could be affected by the chaotic revolution in the neighbouring Portugal.

The peacefully falling down of the twin Portuguese regime in April 1974 had a huge impact in Spain. ${ }^{70}$ Inmovilistas reorganized and started an aggressive campaign against reforms, while the democratic opposition flourished, leading to

66. Madrid: Wieder einmal 'Apertura'-Hoffnungen, in: Parlamentarisch-Politischer Pressedienst, 18.03.1974.

67. A. WILKENS, Willy Brandt und die europäische Einigung, in: M. KÖNIG, M. SCHULZ (eds.), Die Bundesrepublik Deutschland und die europäische Einigung, 1949-2000, Franz Steiner Verlag, Stuttgart, 2004.

68. A. VARSORI (coord.), Alle origini del presente. L'Europa occidentale nella crisi degli anni Settanta, Franco Agneli, Milano, 2007.

69. West Germany's Südpolitik has a marginal place within the huge historical production of Willy Brandt's foreign policy. See O. BANGE, Ostpolitik - Etappen und Desiderate der Forschung. Zur internationalen Einordnung von Willy Brandts Aussenpolitik, in: Archiv für Sozialgeschichte, 46(2006), pp.713-736.

70. J. SÁNCHEZ CERVELLÓ, La revolución portuguesa y su influencia en la transición española (1961-1976), Nerea, Madrid, 1993, chapter V. 
the foundation of a Junta Democrática dominated by the communist party of Santiago Carrillo (PCE). Under growing pressure the Spanish government sent messages to German leaders, "who are the only ones who truly support Spain's efforts to come closer to Europe", to convince them that they should back Carlos Arias' reform program and maintain the expectations of Spain's further approach to the EEC in order to avoid a Portuguese scenario. ${ }^{71}$ The new government of Helmut Schmidt shared this opinion and paid no attention to Spanish democrats, who claimed the EEC should refuse any kind of negotiation with a regime that tried to sell a parody of democratisation in Europe. ${ }^{72}$ Negotiation for a new trade agreement with Spain was relaunched in November 1974, and only the unbridgeable initial positions regarding how far mutual trade concessions should go made a rapid conclusion impossible. ${ }^{73}$ The German position in the following months was that the EEC should accept the Spanish proposal and conclude the new agreement as soon as possible, to add stability to the EEC-Spain relations in that complex period. ${ }^{74}$

But Bonn's confidence in PM Carlos Arias was severely damaged in the first months of 1975. In February, his project suffered a hard knock following Franco's decision not to accept the conditions posed by the most influential reformist of the regime, Manuel Fraga, for creating a "political association". ${ }^{75}$ In the next days, the new German ambassador Georg von Lilienfeld conveyed to Bonn that, against the background of growing labour and communist activism in Spain the country was facing great tensions if the government was unable to free itself from Franco's shadow and relaunch reforms. ${ }^{76}$ This concern turned into panic in mid-March when, in response to a failed coup by right-wing military units, Portugal became within days, "practically, a left military dictatorship". ${ }^{77}$ That same day, when Portuguese communists, as an alarmed Mario Soares informed Helmut Schmidt, seemed to be thinking about seizing power using the same strategy as their Czech comrades in $1948,{ }^{78}$ a large delegation of the Junta Democrática de España was received in Strasbourg by members of the European Commission and Parliament as the democratic alternative to Franco dictatorship. Madrid reacted furiously to the

71. PAAA, Zwischenarchiv 101441, Lilienfeld to Auswärtiges Amt on his meeting with Foreign minister Pedro Cortina, 31.08.1974. The quotation are the Spanish minister's words.

72. PAAA, Zwischenarchiv 105669, manifest subscribed by the leaders of PSOE (Felipe González) and trade union UGT (Nicolás Redondo), and addressed by the secretary general of the Trade Unions Confederation to the president of the EEC Council, 22.11.1974.

73. M. TROUVÉ, L'Espagne et l'Europe. De la dictature de Franco à l'Union européenne, Peter Lang, Bruxelles etc., 2008, pp.154-157.

74. PAAA, Zwischenarchiv 105669, report of Auswärtiges Amt on EEC-Spain relations, 31.01.1975.

75. J. TUSELL, G. QUEIPO DE LLANO, Tiempo de incertidumbre. Carlos Arias Navarro entre el franquismo y la Transición (1973-1976), Crítica, Barcelona, 2003, pp.153ff.

76. PAAA, Zwischenarchiv 110257, Lilienfeld to Auswärtiges Amt on Spanish politics, 06.03.1975.

77. Thus the West German ambassador to Lisbon. PAAA, Zwischenarchiv 113503, Fritz Caspari to Auswärtiges Amt on the failed putch, 14.03.1975.

78. AdsD, NL Bruno Friedrich 1536, note of Bruno Friedrich (foreign policy specialist of the direction of the SPD fraction) to Helmut Schmidt on Mario Soares' message from Lisbon, 21.03.1975. 
fact that European institutions had treated Spanish communists formally as the equivalent of the Spanish state. Lilienfeld backed this opinion and interpreted the affair as a step forward in Carrillo's plan to come to power in Spain just as his comrades were trying to do in Portugal. ${ }^{79}$

Influenced by those events, the SPD concluded by the beginning of the spring of 1975 that Spain, due to the strength of the PCE, faced a real risk of destabilisation. To avoid this danger, the party leader realized that they had to strongly support an alternative left-wing pole as a counterbalance to the communists $^{80}$ in Spain, as they were already doing in Portugal. This could only be the PSOE, for, unlike the other socialist group the SPD was in touch with, the PSOE did not enter the Junta Democrática and its new leader, Felipe González, had given clear signs in the past months that he trusted Prince Juan Carlos as the pilot of the future transition and rejected a Left front with the communists, such as François Mitterrand constantly suggested him. ${ }^{81}$ In April, González was invited for the first time to the SPD's headquarters in Bonn, to meet Willy Brandt and other party leaders, who wanted to provide the PSOE "with all possible assistance and aid". 82 The Spaniard reassured his German comrades concerning his intentions by stating that "the decisive political struggle in the transition period once Franco had passed away, will be between Socialists and Communists". ${ }^{83}$ Standing on this common ground, a long debate followed on specific measures of political, economic and logistical support by the SPD and the Friedrich Ebert Foundation to turn the small PSOE, which had only two paid members (González being one of them), into a mass party that could achieve good results in the first democratic elections. ${ }^{84}$

In response to the insistent requests made by the Spanish government to "support in a friendly manner" the process of transition, ${ }^{85}$ German authorities stressed after the spring of 1975 that the reform project based on "political associations" had already been overtaken by the events in the country, and that the Spanish government should open up a dialogue with the illegal opposition, and especially with the PSOE. This message was conveyed in diplomatic terms by Helmut Schmidt to Arias Navarro during the Helsinki summit in July, ${ }^{86}$ and by Georg von Lilienfeld to Don Juan Carlos. While the Prime minister was very

79. PAAA, Zwischenarchiv 110257, Lilienfeld to Auswärtiges Amt on the Strasbourg facts, 18.03.1975.

80. AdsD, NL Bruno Friedrich 100352, meeting of the committee for international relations of the SPD direction, 21.03.1975.

81. AdsD, SPD Parteivorstand 11423, report of Veronika Isenberg on the meeting of the Spanish Committee of the Socialist International in London at 12 January 1975, 21.01.1975.

82. AdsD, SPD Parteivorstand 11491, Dingels to Brandt on the visit of González the following day, 17.04.1975.

83. AdsD, SPD Parteivorstand 11491, report of Dingels on the meeting with González, 23.04.1975.

84. A. MUÑOZ SÁNCHEZ, La Fundación Ebert y el socialismo español de la dictadura a la democracia, in: Cuadernos de Historia Contemporánea, 29(2007), pp.257-278.

85. AdsD, Helmut Schmidt Archiv 7077, note on a meeting of the chief of the chancelorship with the Spanish minister of Presidency in Bonn at 24 June 1975, 25.06.1975.

86. $A A P D, 1975$, doc. 242. 
reluctant to follow this advice and even rejected Brandt's request that Felipe González be given back his passport so that he could depart upon a European tour organized by the SPD, the Prince backed the idea, and told the ambassador that after having taken office he would be willing to work with all major illegal parties, except the communist party. ${ }^{87}$

The executions at the end of September 1975 of three FRAP (ultra-left organization) and two ETA members provoked a huge international outcry. There were large demonstrations in the most important European cities. In Lisbon, the embassy was destroyed by a fire. The Nine (except Ireland) withdrew their ambassador from Madrid; Mexico claimed the expulsion of Spain from the United Nations, and European trade unions pleaded for an economic boycott of the country. On 1st October, almost one million people gathered in Madrid to respond to those "foreign provocations" and to offer their support to Franco. The German government, fearing that the fury of public opinion would force European governments to isolate Spain, a situation that would just weaken reformists close to Don Juan Carlos and the moderate opposition such as the PSOE, and hinder the peaceful transition even more, decided to calm down tensions, especially within the EEC. ${ }^{88}$ Two days before the executions were carried out, the European Parliament had issued a hard resolution asking the Council to stop relations with Spain as long as democracy had not been re-established. During the Council meeting on 6 October, German Foreign minister Hans-Dietrich Genscher was able to convince his Dutch and Danish colleagues to abstain from the idea of demanding that Brussels should exert real pressure on Spain and to accept a resolution simply stating that "in the present moment, negotiations between the EEC and Spain can not be resumed". ${ }^{89}$ The following days, Lilienfeld was one of the first European ambassadors to return to Madrid. Once again, the German government had decisively contributed to avoid giving Francoist leaders the impression that the Community was above all a fortress of democracy, liberty and human rights where they could never be accepted. ${ }^{90}$

The executions severely damaged the credibility of the Spanish government abroad and even of Prince Juan Carlos, whose capability to manage the complex transition laying ahead was questioned exactly at the moment when he had to take office as chief of State following Franco's illness at the end of October. In this atmosphere of complete uncertainty, ambassador Lilienfeld persistently asked the Prince to force his PM to give Felipe González his passport, which would allow him to attend the SPD congress in Mannheim. This was to be much more than a regular party meeting. The who is who of the European socialism would gather

87. PAAA, Zwischenarchiv 110257, Lilienfeld to Auswärtiges Amt on his meeting with don Juan Carlos, 06.08.1975.

88. PAAA, Zwischenarchiv 110258, note of Auswärtiges Amt on German position to executions in Spain, 30.09.1975.

89. PAAA, Zwischenarchiv 105669, report of Auswärtiges Amt on relations EEC-Spain, 10.10.1975.

90. F. GUIRAO, The European Community's ..., op.cit. 
there, at Willy Brandt's invitation. ${ }^{91}$ The SPD had conceived the congress as the staging of its own leadership of a renovated European democratic left, able to speak (for the first time) a common language and to provide global solutions to the crises of the continent. ${ }^{92}$ By allowing González to attend the congress, Lilienfeld told Don Juan Carlos, the future king would be sending a clear statement to a sceptical Europe on his will to break with Francoism and to start a new era of democratisation and national reconciliation. ${ }^{93}$ The Prince finally managed to impose his will on Arias Navarro in this issue, and Felipe González could fly to Germany and approach the stand of the SPD congress to warn European democrats not to repeat former mistakes. The veteran SPD leaders probably laughed for a while inwardly thinking that, all in all, their strategy of "Europeanising" Franco's dictatorship did not deserve such bad records. In any case, that was not the moment to look backward, but to fully engage in supporting the PSOE, a party that just by case had become a key element in West Germany's policy towards Spain. The dream of any postwar social-democratic government came true: Realpolitik and international solidarity packed in one single strategy.

91. Die Linke auf Tauchstation, in: Die Zeit, 14.11.1975.

92. Up to then, the SPD had shown no interest in coordinating its European policy with other socialist parties. See C. HIEPEL, 'Europa gehört keiner Partei': Die SPD und der Weg vom Socialist Information and Liaison Office zur Sozialdemokratischen Partei Europas, in: J. MITTAG (ed.), Politische Parteien und europäische Integration. Entwicklung und Perspektiven transnationaler Parteikooperation in Europa, Klartext, Essen, 2006.

93. PAAA, Zwischenarchiv 110257, Lilienfeld to Auswärtiges Amt on his meeting with Don Juan Carlos, 10.11.1975. 


\section{Spanien im Wandel}

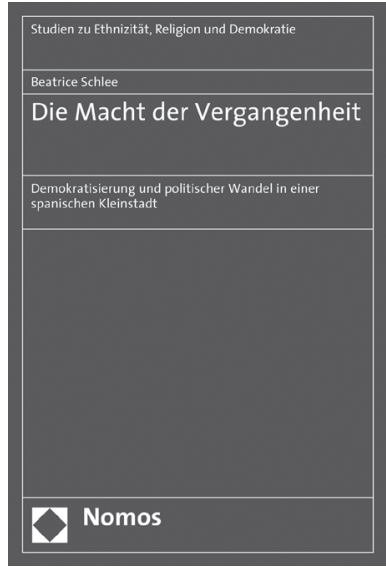

Die Macht der Vergangenheit

Demokratisierung und politischer Wandel in einer spanischen Kleinstadt

Von Beatrice Schlee

2008, 668 S., brosch., 98,-€,

ISBN 978-3-8329-3274-9

(Studien zu Ethnizität, Religion

und Demokratie, Bd. 11)

Wann erreicht ein Demokratisierungsprozess die Bevölkerung? Führt er zwangsläufig zu einem tief greifenden politischen Wandel?

Die Studie verweist auf die Komplexität, mit der die Themen Demokratisierung und Vergangenheitsbewältigung betrachtet werden sollten - und auf die vielen Fallstricke, in die gerade auch die Erneuerer (Opposition und Zivilgesellschaft) geraten können.

"Die Studie ist von beeindruckender Detailliertheit.»

Timo Lüth, ZPol o7/08

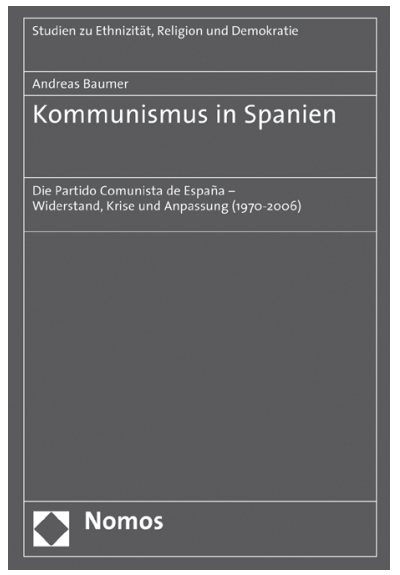

\section{Kommunismus in Spanien}

Die Partido Comunista de España - Widerstand, Krise und Anpassung (1970-2006)

Von Andreas Baumer

2008, 445 S., brosch., 79,- $€$,

ISBN 978-3-8329-3266-4

(Studien zu Ethnizität, Religion

und Demokratie, Bd. 9)

Der vorliegende Band ist die erste umfassende Darstellung der politischen und organisatorischen Entwicklung der Kommunistischen Partei Spaniens (PCE). Einst dominant im antifranquistischen Untergrund und während der Demokratisierung, konnte sich die PCE nach einer Krise mit dem Linksbündnis Izquierda Unida dauerhaft als dritte politische Kraft in Spanien etablieren.

"hervorragend recherchiert"

Natalie Wohlleben, ZPol o8/08 